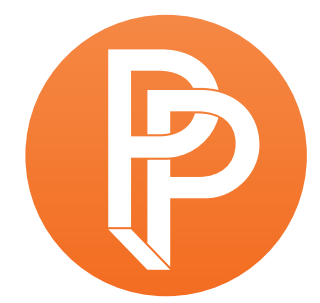

PERFORMANCE

PHILOSOPHY

\title{
FOR COLORED GIRLS WHO'VE CONSIDERED SUICIDE WHILE SURVIVING POST-TRAUMATIC SLAVERY SYNDROME(WITH ACKNOWLEDGEMENTS TO NTOZAKE SHANGE AND DR. DEGRUY)
}

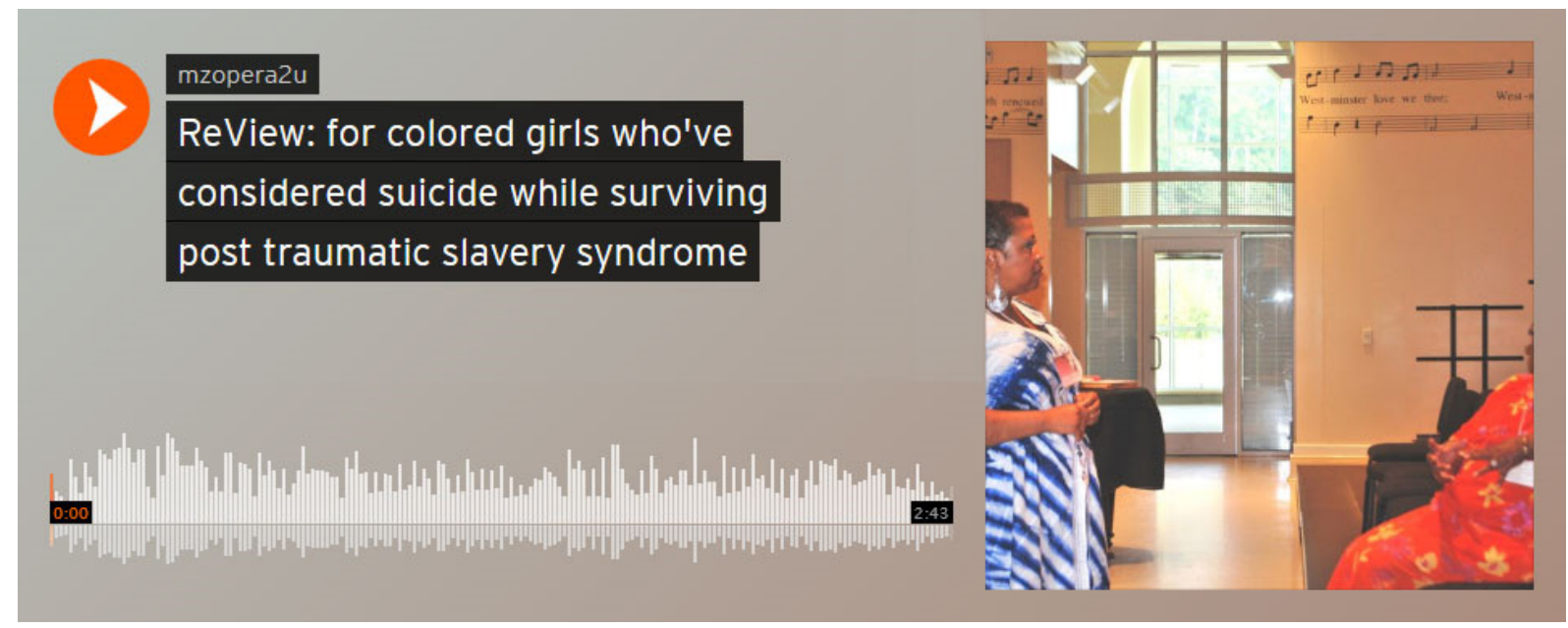

A Listen to this ReView at:

https://soundcloud.com/mzopera2u/sets/performance-philosophy-review/ 


\section{Works Cited}

DeGruy, Joy. 2005. Post Traumatic Slave Syndrome: America's Legacy of Enduring Injury and Healing. Portland OR: Joy DeGruy Publications.

Collins, Patricia Hill. 2000. Black Feminist Thought: Knowledge, Consciousness, and the Politics of Empowerment. London and New York: Routledge.

King, Ruth. 2007. Healing Rage: Women Making Inner Peace Possible. New York: Penguin.

MacGregor, J.C. Chummy, George "The Fox" Williams, and Sunny Skylar, composers. 1942. "It Must Be Jelly 'Cause Jam Don't Shake Like That". Performed by Glenn Miller and His Orchestra, RCA Victor.

Perera, Suvendrini, and Joseph Pugliese. 2011. "Introduction: Combat Breathing: State Violence and the Body in Question." Somatechnics 1 (1): 1-14. https://doi.org/10.3366/soma.2011.0002

Rice, Dana, and Allison Upshaw. 2014. Battles of wounded me: An autoethnographic Cantata (unpublished).

Shange, Ntozake. 1977. for colored girls who have considered suicide / when the rainbow is enuf. New York: Scribner.

Upshaw, Allison. 2017. "My Body Knows Things: This Black Woman's Storied Theory in Performative Autoethnography." In Doing Autoethnography, edited by Sandra L. Pensoneau-Conway, Tony E. Adams, and Derek M. Bolen, 55-65. Boston: Sense Publishers. https://doi.org/10.1007/978-94-6351-158-2_7

\section{Biography}

Allison Upshaw graduates in December 2017 with a PhD in Interdisciplinary Studies from the University of Alabama. Her research areas of interest are aesthetic meaning-making, performance, and arts-based research methods. Allison also holds degrees in vocal performance from Oberlin Conservatory, Louisiana State University, and continues to perform as a recitalist specializing in music by composers of African descent. She is a proud member of Actor's Equity, the professional stage actor's union. Allison is also a Creative Education Consultant/Teaching Artist, and a native of Forest Home, Alabama.

(C) 2017 Allison Upshaw 